206. 透過原稿用スキャナーを画像入力装置として 用いた時の問題点とその補正

\title{
Problems in the use of scanner as an image input equipment
}

\author{
大阪警察病院 放射線技術科 \\ ○多賀井 進藤沢 康雄田中 淳司 \\ (Susumu Tagai) (Yasuo Fujisawa) (Atsushi Tanaka) \\ 山本 剛 富永 聡東出 敏明 \\ 清本 昌義 \\ ( Masayoshi Kiyomoto) \\ 寺田 央
}

(Tsuyoshi Yamamoto)(Satoru Tominaga) (Toshiaki Higashide)

(Hiroshi Terada)

【目 的】

透過原稿用スキャナーは、主にスライドや教育用资料の入力装贯として使用されてい

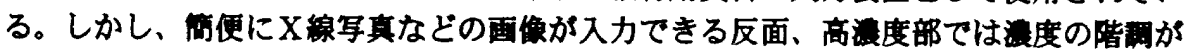
低下する事が一般的に知られている。今回、スキャナーを画像入力装贉として用いた時

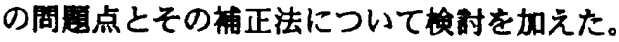

【使用機器】

スクリーン/7仙 : Fufl HR-4/HR-S スキャナー: SHARP JX-325M

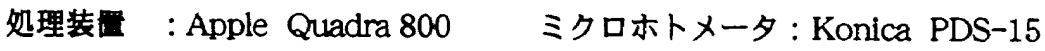

处理ソフト：Scan JX（スキャナー付属ソフトて、カカンマコレクション, Brightness,

Lightnessの設定を変えることができる)

: HIPG DIP Station、Adobe Photoshop (階閁の榑正を行うことができる)

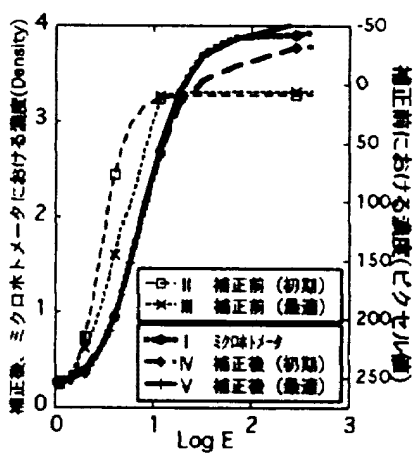

【方 法】

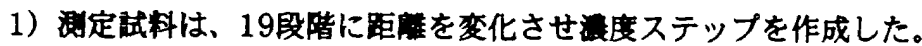

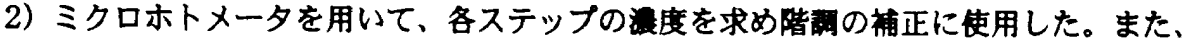
特性曲線(図1-I)は、スキャナーの最䢔設定を求めるのに使用した。

3）同試科を問通点の多い初期設定で就み取った曲線(四1-II)を、図1-Iに近似するため にDIP Stationにて階嗍の補正を行った。

4）まず、スキャナーの㿞道設定值を求めた。カンマコレクションは中間同を決定するの て、四1-I と同じ䫅きになるような值を求めた後、Brightnessは高湌度(シャドウ)部分

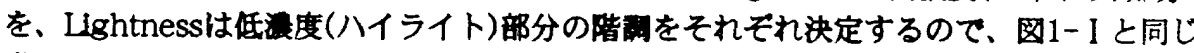
階調となるような值を求めた。次に、同䀦枓を最道設定て娔み取った曲線(図1-而)を、 図1-Iに近似するためにDIP Stationにて降网の㭪正を行った。

5）方法3，4)により求めた特性曲線およびパーカー氏ファントムの比校を行った。

【結果およひ青宗】

(1)方法3)の初期殿定で誖み取り、階网の補正を行った結果を図1-Nに示す。四1-Iに近 似するためには、因2-aの大幅な榑正曲線が必要となった。

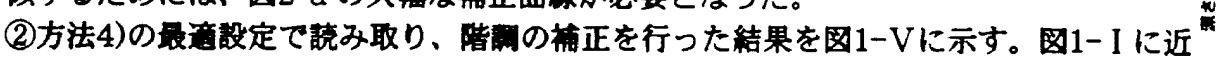

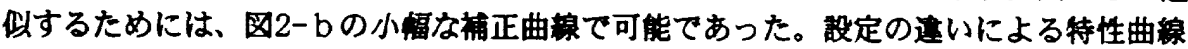

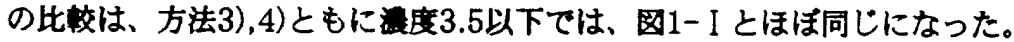

(3)バーガー氏ファントムの比較(図3)では、方法3)は大幅な榑正となるため、トーンジャ ンブが生じ、コントラスト分解能が低下した。四4は、胸部写真のヒストグラムて、、補正 が大きくなるほどトーンジャンブが多く発生した。よって、方法4)のように、最道設定 で読み取り、小幅な階韧の載正で済むようにすることが重要であった。

(4)DIP StationはX線画像処理専用ソフトであるが、一般的なAdobe Photoshopでも同 様な階洞の補正を行うことができる。

【結 常】

JX-325Mにおいては、ガンマコレクション=モニター用, Brightness=4, Lightness= -10 の最通設定を求めることができた。しかも、これらはスキャナー固有の設定值であ るので、一度設定すれば良い。

階雨の榑正を行うことにより、高流度域もカバーした広いタイナミックレンジが得ら れるが、大愊な㭪正ではトーンジャンブが多く発生した。よって、最も原画像に近い画 像が得られるのは、最暗設定で読み取り、小幅な韨正で清むようにする方法である。

1 補正前後の特性曲線の比較

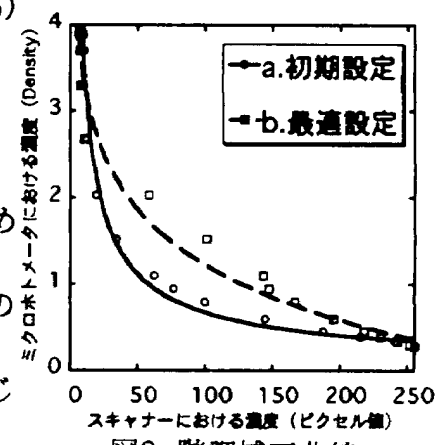

図2 階調補正曲線

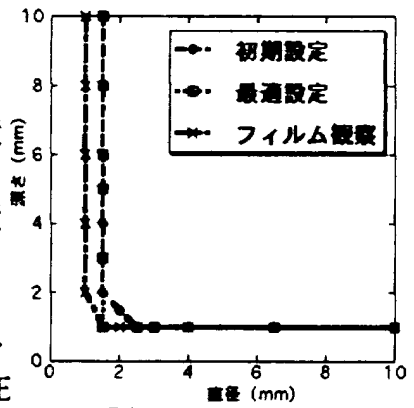

図3 視覚的評価
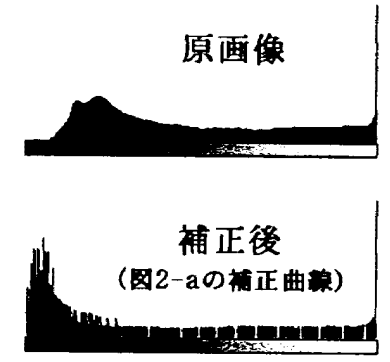

図4 胸部写真のヒストグラム 